Unwin, Ltd., 4s.). The report gives inter alia a general account of the measures adopted in China, with a summary of the work being done in the province of $\mathbf{K}$ wang-si, the most advanced province as regards the organization of social services. Informa. tion on the United States and the United Kingdorn is very complete. The report should prove useful to all who are interested in the social development of various countries and tho measures adopted to protect the mother and child.

\section{Safeguarding Water Supplies}

A MEMORANDus sotting out the precautions nocessary in the administration of a water supply undertaking in order to maintain tho wholesomeness of the supply has been sent by tho Minister of Health to all water undertakings ("Memorandum on the Safeguards to bo Adopted in Day to Day Administration of Water Undertakings". Mem. 221. H.MI. Stationery Office). Theso precautions aro thoso that have long been recognized as good practice in water administration, and include caro in tho solection of workmen so as to exclude possible infection through carriers, pasticularly during repair work, inspection of gathering grounds, froquent and regular analyses of the water supplied, and the use of special treatment such as chlorination.

\section{Research in the London Hospital}

The Publications Committec, with Prof. Bedson as its secretary, has issued a volume of "Researches Published from the Wards and Laboratories of the I ondon Hospital during 1938" (London: H. K. Lewis and Co., Ltd., $78.6 d$. net). It includes thirty. seven papers dealing with a wide range of subjectsphysiological, pathological, biochemical and clinical - which are evidence, if that were needed, of the active studies upon problems of health and of disease that aro being pursued at this great medical school and hospital.

\section{Studentships and Fellowships in Medical Research}

Tнғ: Medical Research Council invites applications for a fourth series of studentships and fellowships intended to encourage young British medical graduates towards becoming investigators in those branches of medical science which are concerned directly with disease as it occurs in human beings. Post-graduate studentships are offered for medieal graduates who have already held house appointments and are strongly inclined to a career in clinical science or experimental pathology. Each selected student will receive a stipend at the rate of $£ 200$ per annum, during a period not exceeding twelvo months, for personal maintenance while undertaking approved courses of study in Great Britain such as may bo regarded as best calculated to advance the student's training in methods of research. Research fellowships are also offered for candidates of similar qualifications who have already had some experience in the use of research methods. Each fellowship will be tenable for one year at the ordinary value of $£ 250$ per annum, and will be renewable in approved instances at the rate of $£ 300$ per annum for a second year. Theso fellowships are intended as probationary appointments for research in clinical science or experimental pathology under suitable direction in Great Britain. Research expenses may be provided in addition to stipend. Further information can be obtained from the Secretary, Medical Research Council, 38 Old Queen Street, I,ondon, S.W.1.

\section{Announcements}

Prof. A. J. Clark, professor of materia medica in the University of Edinburgh, and Prof. T. R. Elliott, emeritus professor of medicine in the University of London and consulting physician to University College Hospital, have been appointed members of the Medical Research Council, in succession to Prof. II. S. Raper and Prof. J. A. Ryle, who retire in rotation on September 30 .

Dr. Dean Burk, formerly chemist in the Bureau of Chemistry and Soils, U.S. Department of Agriculture, has been appointed senior chemist in the newly established National Cancer Institute, U.S. Public Health Service, and associate professor of biochemistry at Cornell University Medical College in New York City, where a study on tissue metabolism fundamental to cancer will bo carried out under the auspices of a grant mado by the National Advisory Cancer Council to the Department of Biochemistry headed by Prof. Vincent du Vigneaud. Collaborating in the investigations will bo Dr. Fritz. Iipmann, formerly research thssocinte of Prof. Otto Meyerhof and of Dr. P. A. Ievene of the Rockefeller Institute, and lately with Dr. Albert Fischer at tho Carlsbergfondets Biologisko Institut, Copenhagen.

Dr. Friedrich Karl Klene, honorary professor of hygieno in the University of IBerlin and an expert on tropical discases, has recently been awarded tho Shicld of Nobility of the Reich by the German Chancellor.

Prof. ILUDwia Jost, professor of botany in the University of Heidelberg, has been awarded the Charles R. Barnes honorary lifo membership of the American Society of Plant Physiology.

THE Autumn Meeting of the Iron and Steel Institute will be held in Cardiff during September 12-15. Further information can be obtained from the Secretary, Iron and Steel Institute, 4 Grosvenor Gardens, I,ondon, S.IV.1.

'TuE John Burroughs Association desires to get in touch with organizations throughout the world which have been formed in honour of John Burroughs, the American poet and naturalist, with the view of collecting opinions concerning an annual publication containing reports of such organizations and articles on Burroughs. Communications should be addressed to the president of the Association, Dr. Clyde Fisher, American Museum of Natural History, 77th Street and Central Park West, New York City. 